\section{LIMITATION OF BACTERIA BY MICRO-PREDATORS IN SOIL}

\author{
By Dr. F. J. ANSCOMBE \\ AND
}

DR. B. N. SINGH

Rothamsted Experimental Station, Harpenden, Herts

$\mathrm{E}$ IGH'TY-SEVEN strains of very varied bacteria, comprising common and rare strains from soil, pigmented and non-pigmented 'miscellaneous' strains, and a number of plant pathogens, were tested on eight micro-predators belonging to four different groups commonly found in soil. The methods used and the results obtained are given by one of us (B. N. S.) in papers dealing with these groups ${ }^{1-10}$. It has been shown that soil micro-predators are very selective in their bacterial food requirements; some bacteria are edible and the others are completely or almost completely inedible. This article deals with the comparative edibility of bacterial strains by these micro-predators, and the probable role of

Small soil amœba
Inedible
Edible
Total
D. mucoroides
Inedible
Edible
Total

C. exiguus
Not lysed
Iysed
Total

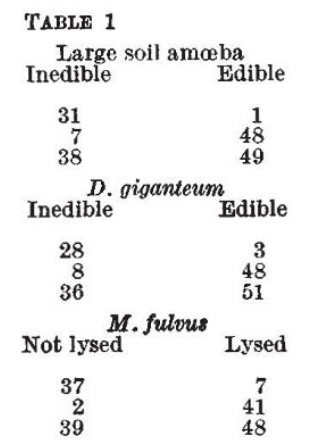$$
\text { Total }
$$

one amœba were edible to the other. Similarly, the myxamceb of the two Dictyostelium spp. were very similar in their food preferences, as were also two of the myxobacteria, namely, Myxococcus fulvus and Chondrococcus exiguus. This is shown in detail, in $2 \times 2$ contingency tables, in Table 1 .

Disregarding now one member of each of these three pairs of micro-predators, we consider the following five predators: large soil amœba, a giant amœboid organism (Leptomyxa reticulata), myxamœba of Dictyostelium giganteum and two myxobacteria (Myxococcus virescens and $M$. fulvus). These five are but slightly correlated in their choice of bacterial food. Their relation in pairs is shown in Table 2 . It will be seen that there is some tendency, but not very pronounced, for bacteria that are edible to one predator to be edible to any other one. In fact, the number of bacterial strains that are edible or inedible to both of any two predators is of the order of 6 higher than it would be if the two predators made a completely independent selection of bacterial food. There is, however, one exception to this rule, as there appears to be no such correlation between Myxococcus virescens and Leptomyxa reticulata.

$$
\begin{gathered}
\text { Leptomyxa reticulata } \\
\text { Inedible } \\
\text { Edible } \\
\text { Total }
\end{gathered}
$$$$
\begin{array}{cc}
\text { Large soil amœba } \\
\text { Inedible }
\end{array}
$$$$
\text { Total }
$$

Total

micro-predators in limiting the bacterial numbers in the soil. The following soil micro-predators were used : two unidentified species of amœbæ, a giant amœboid organism (Leptomyxa reticulata Goodey), myxamœbæ of two species of Dictyostelium (D. mucoroides and $D$. giganteum) and three species of Myхососcасеæ (Myxococcus virescens, $M$. fulvus and Chondrococcus exiguus). The first five organisms are holozoic; the Myxococcaceæ destroy and digest their food by means of secretions ${ }^{6,10}$.

of the eight micro-predators tested, it was found that the two soil amœbæ reacted very similarly to their bacterial prey; that is, nearly all bacteria edible to
To make this clear, consider the relation of the large soil amœba and $L$. reticulata (Table 3 ). If the two predators made independent selections of host bacteria, we should have expected that $48 / 87$ of the 38 bacterial strains inedible to the soil amoeba would have been inedible to $L$. reticulata also, that is, about 21, in place of the 27 actually observed. Similarly, we should have expected the number of bacteria edible to both the predators to have been 22 instead of 28 , and the two remaining entries to have been each 6 larger, that is, 27 and 17 instead of the 21 and 11 .

Considering now the five micro-predators together, we obtain Table 4, showing how many of the 87 bacterial strains tested are edible to $0,1,2,3,4,5$ of the micro-predators. Thus seven strains are inedible to all predators while thirteen are each attacked by only one predator.

The calculated numbers shown in the last column were obtained assuming that the bacterial strains vary in their intrinsic edibility, some being more

TABLE 2

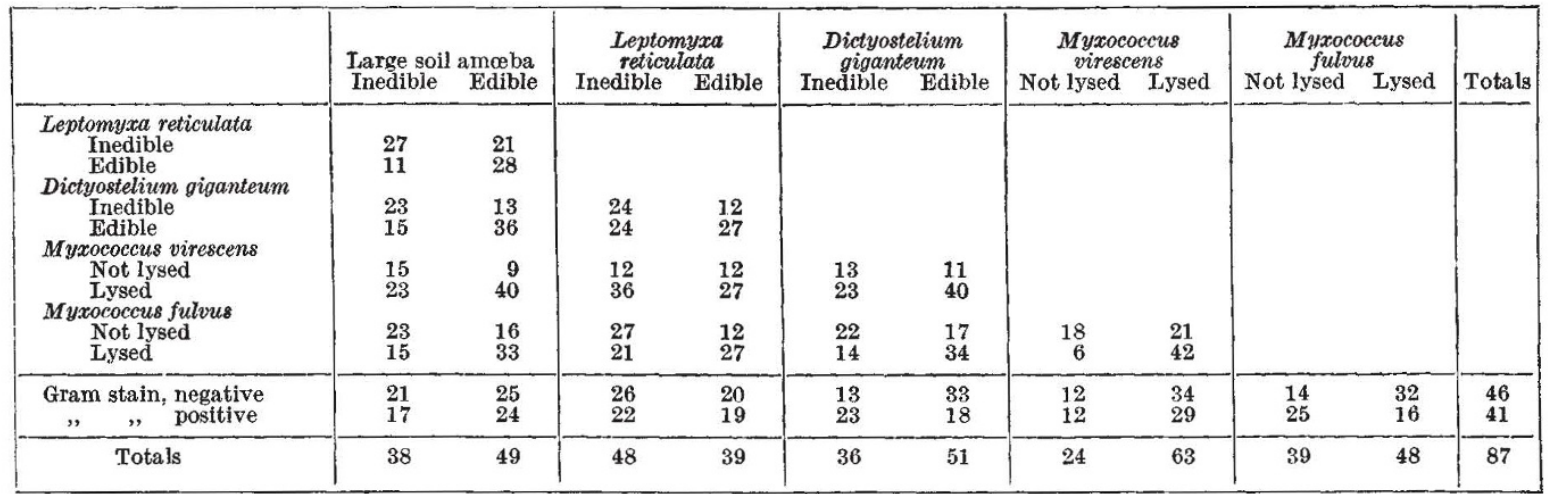

N.B.-The edible and lysed strains are those which are completely eaten and completely lysed either slowly or readily; inedible and non-lysed strains also include those bacteria which are either very slightly eaten or show very slight lysis. 
TABLE 4

\begin{tabular}{|c|c|c|}
\hline $\begin{array}{c}\text { Number of preda- } \\
\text { tors (out of 5 con- } \\
\text { sidered) }\end{array}$ & $\begin{array}{c}\text { Observed number of } \\
\text { bacterial strains } \\
\text { attacked by the fore- } \\
\text { going numbers of } \\
\text { predators }\end{array}$ & $\begin{array}{c}\text { Calculated number of } \\
\text { bacterial strains }\end{array}$ \\
\hline 0 & 7 & $6 \cdot 7$ \\
1 & 13 & $12 \cdot 1$ \\
2 & 13 & $16 \cdot 1$ \\
3 & 25 & $18 \cdot 5$ \\
4 & 12 & $15 \cdot 6$ \\
\hline 5 & 87 & $87 \cdot 0$ \\
\hline Total & 17 & \\
\hline
\end{tabular}

edible to predators than others, but that otherwise it is a matter of chance whether any one strain is edible to any one predator, and there is no tendency for predators to feed complementarily (that is, one generally preferring strains left uneaten by another). The actual mathematical distribution assumed, a type of modified binomial distribution, will shortly be described elsewhere by one of us (F. J. A.). It will be seen that the calculated numbers agree well with the observed.

Thus of the eight micro-predators tested together, five behave in the way just described, showing some tendency, but not a very pronounced one, to feed on the same selection of host bacteria; whereas the remaining three predators are each highly correlated. with one of the five already considered, and so not likely to affect appreciably the total number of bacterial strains edible to one or more of the predators. It is interesting to consider, as a matter of speculation, what percentage of the bacterial strains tested would remain inedible by any predator if more predators could be found having the same degree of independence from the five here considered and from one another as these five have from one another. We should expect the percentage of uneaten strains to vary with the total number of predators as shown in Table 5 .

TABLI 5

$\begin{array}{cc}\text { Number of different predators } & \% \text { of strains uneaten } \\ 5 & 7 \cdot 7 \\ 6 & 5 \cdot 9 \\ 10 & 2 \cdot 6 \\ 15 & 1 \cdot 3 \\ 20 & 0 \cdot 8\end{array}$

In Table 2 is also shown the relation of the five micro-predators to the Gram-staining of the bacterial strains. Two of the predators, Dictyostelium giganteum and Myxococcus fulvus, show a definite negative association, suggesting that they prefer bacterial strains that are Gram-negative. The same will also apply to the similarly behaved Dictyostelium mucoroides and Chondrococcus exiguus. It should be remembered that many soil organisms such as antibiotic actinomyces and fungi show a strong preference for Gram-positive bacteria. Such organisms will thus tend to be complementary to the above predators in their food preferences.

The remaining predators tested do not show any such association with the Gram-reaction.

\footnotetext{
' Singh, B. N., Ann. Appl. Biol., 28, 52 (1941).

'Singh, B. N., Ann. Appl. Biol., 29, 18 (1942).

'Singh, B. N., Brit. J. Exp. Path., 26, 316 (1945).

- Singh, B. N., Ann. Appl. Biol., 33, 112 (1946).

'Singh, B. N., Nature, 157, 133 (1946).

- Singh, B. N., J. Gen. Microbiol., 1, 1 (1947).

'Singh, B. N., J. Gen. Microbiol., 1, 11 (1947).

- Singh, B. N., J. Gen. Microbiol., in the press.

- Singh, B. N., J. Gen. Microbiol., in the press.

${ }^{10}$ Oxford, A. E., and Singh, B. N., Nature, 158, 745 (1946).
}

\section{RESEARCH AND DEVELOPMENT IN BRITISH COLONIAL TERRITORIES}

\section{Colonial Research Committee}

$\mathrm{T}$ HE fourth annual report of the Colonial Research Committee, published under the title "Colonial Research 1946-47"*, together with the fourth annual report of the Colonial Products Research Council, the third annual report of the Colonial Social Science Research Council and the second annual reports of the Colonial Medical Research Committee and of the Committee for Colonial Agricultural, Animal Health and Forestry Research, covers the period April 1, 1946-March 31, 1947, and refers again to the lightening of the task of the Committee by the creation of separate bodies to advise the Secretary of State on special aspects of reseach. Early in 1947, the Colonial Insecticides Committee was created, with Sir Ian Heilbron as chairman, to initiate research, including experimental field work, to examine schemes for research and experiment submitted by Colonial Governments or other appropriate bodies, to advise on problems concerning the use of insecticides, and to make available the latest scientific information to those concerned with the use of insecticides in the Colonies. This Committee has already decided to concern itself primarily with the experimental application of the results of fundamental insecticide research, but will also encourage and reinforce research projects of Colonial Government Departments as well as co-ordinate agricultural, medical and veterinary interests in the use of insecticides. Economic research has now been entrusted to a Colonial Economic Research Committee, with Sir Arnold Plant as chairman, which, working in close association with the Colonial Social Science Research Council, will advise the Secretary of State on economic research and statistics.

While the Colonial Research Committee continues to act as the central advisory body on expenditure schemes initiated by the other bodies, with the exception of the Colonial Products Research Council, its own report becomes essentially a cover note appended to the list of schemes approved for research grants, although the whole report is a most useful reference paper in view of the information it contains concerning membership of the various committees, etc. Referring to Dr. E. B. Worthington's appointment as joint secretary to the Committee, the report states that Dr. Worthington's services have been placed at the disposal of the East African Governor's Conference for a period of two years, to advise on the regional organisation of research in the three East African territories in which the Governor's Conference is interested. The Central African Council, established in 1945 as a consultative body to foster co-operation between Southern Rhodesia, Northern Rhodesia and Nyasaland, also decided to appoint a research secretary to survey existing facilities for research and report upon additional facilities required; but no definite steps were taken to consider the regional organisation of research in West Africa. Five Colonial Research fellowships were awarded during the year, but one was ultimately declined by the applicant.

- Colonial Offce. Colonial Research 1946-47. Pp. ii+72. (Cmd. 7151.) (London: H.M. Stationery Office, 1947.) 18. 3d. net. 